\author{
Ivana Đuras, \\ viša ustavnosudska savjetnica, Ustavni sud Republike Hrvatske
}

\title{
SAVJESNOST I POŠTENJE U SUDSKOJ PRAKSI
}

\author{
$U D K: 342$ \\ DOI: $10.31141 /$ zrpfs.2019.56.133.705 \\ Stručni rad \\ Primljeno: 1. 03. 2019.
}

Još su obvezni odnosi rimskoga prava bili zaštićeni tužbama, actiones bonae fidei, ako su bili zasnovani na načelima dobre vjere - bona fides i pravičnosti - aequitas. Kako tada, tako i danas, sudac donoseći presudu u povodu takvih tužbi mora ispitati sve činjenice i okolnosti koje su pratile zaključenje pravnog posla, kako bi donio valjan i na zakonu osnovan pravorijek. Članak koji slijedi prikazuje neke aktualne primjere iz sudske prakse, u kojima je vidljivo postupanje redovnih sudova prilikom odlučivanja o obveznim odnosima u kontekstu načela savjesnosti i poštenja, a prikazane su i odabrane odluke Ustavnog suda Republike Hrvatske koje su obuhvatile problematiku savjesnosti i poštenja u obveznim odnosima kroz prizmu temeljnih, ustavom zagarantiranih ljudskih prava i ocjenu eventualne povrede istih.

Ključne riječi: savjesnost, poštenje, bona fides

\section{UVOD KROZ POVIJEST NAČELA}

Bona fides u obveznom pravu temeljno je načelo za velik broj raznih pravnih odnosa, osobito s područja konsenzualnih i realnih kontrakata, koje je Justinijan ${ }^{1}$ proširio gotovo na cjelovito obvezno pravo. ${ }^{2}$

U razvitku rimskog prava, posebno u procesu priznavanja tipičnih ugovora obveznog prava, važnu je ulogu imalo ius gentium kao pravni sustav koji je nastao djelatnošću peregrinskog pretora, primjenjivao se u odnosima između peregrina iz raznih provincija ili između Rimljana i peregrina, a peregrinski je pretor, stvarajući taj pravni sustav, postavljene probleme i sporove rješavao prilagođavajući ustanove ius civilea peregrinima ili uzimajući najbolja rješenja iz pravnih sustava provincija.

1 Ant. razvoj rim. prava zaključio je car Justinijan svojom kodifikacijom (528. - 534.), poslije nazvanom Zbornik civilnoga prava (Corpus iuris civilis), najvažniji dio koje su Digesta (Pandectae), zbirka pravnih rješidbi klasičnih rim. pravnika. Justinijanova kodifikacija, kojom su i rimski pravni izvori bili sustavno sređeni i zakonski osnaženi, iznimno je ostvarenje univerzalne i neprolazne vrijednosti, kojim je rimska pravna tradicija sačuvana za buduće naraštaje. izvor, http://www.enciklopedija.hr/ natuknica.aspx?id=52921, posjećeno 8. lipnja 2018.

2 Justinijan (527. - 565.) bio je posljednji car koji je uspio ujediniti najveći dio zemalja istočnog i zapadnog dijela carstva. Već na početku vladavine odlučio je kodificirati cjelokupno rimsko pravo: ius i leges. Kodifikatorni posao povjeren je komisiji koju su sačinjavali istaknuti pravnici i profesori na čelu s Tribonijanom, predstojnikom carskog ureda. Rad na kodifikaciji započeo je 528. godine, da bi već 529 . stupio na snagu Codex Iustinianus, zbirka carskih konstitucija izdanih prije Justinijana i prilagođenih novim potrebama. Taj kodeks nije sačuvan. 
Peregrinski pretor, za razliku od gradskog pretora, nije bio vezan civilnim pravom pa je bio u mogućnosti davati jednostavna i elastična rješenja i stvarati nove ustanove, što je iznjedrilo pravni sustav koji je bio puno jednostavniji, praktičniji i potpuniji od rimskog civilnog prava. Zbog toga su se i sami Rimljani u svojim međusobnim odnosima sve više koristili pravilima ius gentiuma, a pod utjecajem tog pravnog sustava, čije ustanove i načela, kao npr. konsenzualni kontrakti i važno načelo bona fides, postupno prodiru u ius civile, počinju popuštanja formalizma, strogosti i apstraktnosti civilnog prava od sredine 3. st. p. n. e. Tako su se sustav honorarnog prava $^{3}$ u koji u šrem smislu spada i ius gentium i sustav civilnog prava postupno počeli preplitati te sredinom Principata, s nestajanjem razlike između Rimljana i peregrina, došlo je i do stapanja sustava ius gentium i civilnog prava.

Zakonom o obveznim odnosima ${ }^{4}$ u Općem je dijelu, Osnovnim načelima, u članku 4. koji sam nosi naslov "Načelo savjesnosti i poštenja" propisano da su se u zasnivanju obveznih odnosa i ostvarivanju prava i obveza iz tih odnosa sudionici dužni pridržavati načela savjesnosti i poštenja.

Na spomenuto načelo često se pozivaju stranke u sudskim postupcima, posebice u parnicama u kojima se odlučuje o gubitku prava iz ugovornih odnosa. No, navedeno načelo u specifičnom obliku poznaje i razdoblje vladavine rimskih careva iz dinastije Severa ${ }^{5}$ tijekom drugog i trećeg stoljeća, u kojem je potkraj klasičnog razdoblja rimska jurisprudencija dosegnula uzor u zakonodavstvu, pravnoj praksi i pravnoj teoriji koja će se nastaviti razvijati na temeljima pravnog klasicizma idućih tisućljeće i pol. U djelovanju Julija Paula, ${ }^{6}$ Papinijana i Ulpijana nastaju glasovite pravne kovanice poput bona fides, ${ }^{7}$ bona fides non partitur, ut bis idem exigatur, ${ }^{8}$ odnosno načelo prema kojem su u međusobnim odnosima stranaka u sporu ili postupcima pred magistratima (pretorima, sudovima) ${ }^{9}$ morali postojati pravednost, pravičnost, poštenje, povjerenje ili korektnost, odnosno uvažavanje ponekad i specifičnih međuodnosa koji nisu uvijek bili usklađeni s važećim normama toga vremena. Razmišljajući o rimskoj bona fides, nameće nam se pojam aequitas, ${ }^{10}$ danas možda najučestaliji izraz i ustavnog i konvencijskog prava, sadržan u članku

3 Ius honorarium.

4 "Narodne novine" broj 35/05, 41/08, 125/11, 78/15, dalje: ZOO.

5 Godine 193. - 235., Paulo, Sentencije (1989.), Latina et graeca, Zagreb, Sentencije, str. 5.

6 "Paulo je bio učenik Cervidija Scevole, jednog od najpoznatijih pravnika II. stoljeća n.e. O njegovu ugledu najbolje govori činjenica da je bio pravni savjetnik cara-filozofa Marka Aurelija. Ne manji dokaz Scevolina znanja i autoriteta je i okolnost da je, po svemu sudeći, on bio učitelj najvećeg rimskog pravnika Papinijana a ni drugi učenik - Paulo - nije mnogo manje pridonio ugledu svoga učitelja. (...) str. 9 .

Svoju profesionalnu karijeru nakon školovanja kod Scevole Paulo je započeo kao advokat.”, ibidem,

7 Dobra vjera, savjesnost, poštena namjera, ispravno uvjerenje (o osnovanosti stjecanja), Romac, Ante, Rječnik latinskih pravnih izraza (1992.), Informator, Zagreb, str. 63.

8 Dobra vjera (poštenje) ne dopušta da se dva puta traži ista stvar, ibidem, str. 63.

9 Kriterij kojim se pretor rukovodio bilo je načelo pravičnosti (aequitas). Primjenom tog načela stvarana su nova pravna pravila i zaštićeni novonastajući odnosi u koje su stranke ulazile oslanjajući se na savjesnost i poštenje suugovaratelja. Sve više se uvažava bona fides (dobra vjera) koja se u pravnim poslovima bonae fidei pretvara u pravni pojam.

10 Jednakost, jednakopravnost, u smislu pravičnosti, odnosno jednaki položaj stranaka. 
29. stavku 1. Ustava Republike Hrvatske ${ }^{11}$ koji je propisao da svatko ima pravo da zakonom ustanovljeni neovisni i nepristrani sud pravično odluči o njegovim pravima i obvezama. Navedenom članku Ustava imanentan je članak 6. stavak 1. Konvencije za zaštitu ljudskih prava i temeljnih sloboda ${ }^{12}$ koji jednako propisuje pravo na pošteno suđenje i nepristrani sud koji pravično treba ispitati određeni slučaj.

\section{PRAKSA REDOVNIH SUDOVA}

U praksi redovnih sudova također nailazimo na korištenje načela savjesnosti i poštenja. Primjerice u predmetu Županijskog suda u Osijeku ${ }^{13}$ odbijen je tužbeni zahtjev tužitelja koji je od tuženika tražio isplatu otpremnine u iznosu od 43.586,64 kuna. Tužitelj je podnio ustavnu tužbu ističući da je u drugostupanjskom postupku pogrešno primijenjeno materijalno pravo, da ima pravo na otpremninu jer smatra da nije otpustio dug tuženiku, s obzirom na to da pravo na isplatu otpremnine podnositelju proizlazi iz sklopljenog ugovora o radu te se on tog prava ne može odreći prije nego ono dospije, a dospjelo je danom raskida ugovora o radu. Zbog navedenoga, smatrao je da nije postupao suprotno načelu savjesnosti i poštenja iz članka 12. Zakona o obveznim odnosima. ${ }^{14}$ Ustavna tužba tužitelja odbijena je kao neosnovana ${ }^{15}$ sa sljedećim obrazloženjem:

„Drugostupanjski sud utvrđuje da je u prvostupanjskom postupku činjenično stanje pravilno utvrđeno, ali da je materijalno pravo pogrešno primijenjeno te stoga odbija tužbeni zahtjev.

U postupku je utvrđeno da su stranke sklopile ugovor o radu na određeno vrijeme do četiri (4) godine za poslove i zadatke direktora tuženika. Člankom 11. ugovora stranke su ugovorile da u slučaju raskidanja radnog odnosa podnositelju pripada pravo na isplatu šest neto plaća isplaćenih u posljednjem mjesecu rada.

Prijedlog podnositelja da se radni odnos sporazumno raskine zbog njegovog odlaska na rad u drugo poduzeće, tuženik je prihvatio, te su stranke nakon toga sklopile sporazum o prestanku ugovora o radu 16. srpnja 2006. Tim su ugovorom stranke utvrdile da podnositelju radni odnos prestaje 16. srpnja 2006., a u točki II. je navedeno da je podnositelj izvršio primopredaju svih zaduženja koje je imao kod poslodavca, te da stranke jedna prema drugoj nemaju nikakvih potraživanja.

Drugostupanjski sud utvrđuje da navedeni ugovor o radu ima elemente menadžerskog ugovora (mješoviti pravni posao), te da odredba članka 11. ugovora

\footnotetext{
11 "Narodne novine" broj 56/90., 135/97., 113/00., 28/01., 76/10. i 5/14.

12 "Narodne novine - Međunarodni ugovori” broj 18/97., 6/99. - pročišćeni tekst, 8/99. - ispravak, 14/02. i 1/06., 6/99.

13 Presudom broj: Gž-1178/07-2 od 18. listopada 2007. uvažena je žalba tuženika Njive d.o.o. iz Lila te je preinačena presuda Općinskog suda u Našicama broj: P-412/06-7 od 12. veljače 2007. godine.

14 "Narodne novine" broj 53/91., u daljnjem tekstu: ZOO.

15 Broj odluke Ustavnog suda RH: U-III-4472/2007 od 11. lipnja 2008.
} 
predstavlja menadžerski dio ugovora te ju treba procjenjivati po odredbama obveznog prava.

Drugostupanjski sud utvrđuje da je usmeni dogovor između stranaka glede isplate otpremnine bio da se podnositelju isplati šest (6) neto plaća tek nakon isteka roka na koji je ugovor sklopljen ako isti ne bude produljen. S obzirom na takovo usmeno utanačenje između stranaka, po stajalištu tog suda podnositelj je otpustio dug tuženiku na temelju članka 344. ZOO-a, te je otpustom duga (koje je učinjeno navedenim sporazumom od 16. srpnja 2006.) prestala obveza na isplatu otpremnine.

Također drugostupanjski sud ističe da je protivno načelu savjesnosti i poštenja da se ugovornoj stranci prizna pravo na isplatu tako ugovorene otpremnine kada je ugovor nakon godine i pol obavljanja dužnosti direktora raskinut zbog prelaska na posao kod drugog poslodavca, a isplata otpremnine je utanačena nakon isteka roka od četiri godine na koje razdoblje je ugovor sklopljen.

3.2. Pravna stajališta navedena u osporenoj presudi drugostupanjskog suda zasnivaju se na pravilnoj primjeni mjerodavnog materijalnog prava i na ustavnopravno prihvatljivom tumačenju tog prava. Ustavni sud utvrđuje da je nadležni sud, polazeći od činjeničnog stanja utvrđenog u provedenom dokaznom postupku, obrazložio svoja stajališta, za koja je nedvojbeno da nisu posljedica proizvoljnog tumačenja i samovoljne primjene mjerodavnog materijalnog prava.“

U idućem promatranom predmetu, presudom Županijskog suda u Zagrebu ${ }^{16}$ odbijen je tužbeni zahtjev podnositelja u kojem je od tuženika zatražena isplata naknade za oduzeto vozilo. Tužbom od 26. veljače 2003. od tuženog obrta "Autocentar Integra" iz Zagreba, tužitelj je zatražio predaju osobnog automobila - vlasništvo tužitelja, koje je tuženik zadržao u svom posjedu nakon izvršenog popravka. Prije donošenja odluke o osnovanosti tužbenog zahtjeva, prvostupanjski je sud na zahtjev podnositelja donio rješenje o privremenoj mjeri kojom je naloženo oduzimanje vozila iz posjeda tuženika i predaja istog podnositelju kao tužitelju. Tijekom provođenja ovrhe navedenog rješenja utvrđeno je da se predmetno vozilo više ne nalazi u posjedu tuženika, o čemu se na očevidu očitovao vlasnik. Budući da je zbog navedene činjenice provedba rješenja o privremenoj mjeri postala nemoguća, podnositelj je, služeći se ovlastima propisanima člankom 191. stavkom 2. Zakona o parničnom postupku, ${ }^{17}$ podneskom preinačio tužbeni zahtjev, te od tuženika na temelju iste činjenične osnove - odbijanje povrata posjeda vozila - zatražio isplatu naknade $\mathrm{u}$ visini protuvrijednosti vozila. ${ }^{18} \mathrm{U}$ ponovljenom postupku, podnositelj je kao tuženika naveo vlasnika obrta "Autocentar Integra" iz Zagreba. Provedeno je

16 Broj: Gž-3003/10-2 od 3. rujna 2011. uvažena je žalba tuženika, vlasnika obrta "Autocentar Integra” iz Zagreba i preinačena presuda Općinskog građanskog suda u Zagrebu broj: P-5815/07 od 21. travnja 2009.

17 "Narodne novine" broj 53/91., 91/92., 112/99., 117/03., 84/08. i 123/08.

18 Presudom broj: P-2459/03 od 6. srpnja 2005. Općinski sud u Zagrebu usvojio je tužbeni zahtjev podnositelja i naložio tuženiku da podnositelju isplati vrijednosnu naknadu za vozilo čiju predaju odbija izvršiti. Županijski sud u Zagrebu rješenjem broj: XXIII. Gž-1761/06-2 od 13. ožujka 2007., zbog bitne povrede parničnog postupka iz članka 354. stavka 2. točke 11. u vezi s točkom 8. ZPP-a ukinuo je prvostupanjsku presudu i predmet vratio na ponovni postupak. 
prometno vještačenje na okolnost stvarne vrijednosti oduzetog vozila te je podnositelj uskladio tužbeni zahtjev u odnosu na visinu zatražene naknade za vozilo, kako je to procijenjeno vještačenjem. Presudom broj: P-5815/07 od 21. travnja 2009. Općinski građanski sud u Zagrebu usvojio je tužbeni zahtjev podnositelja i tuženiku naložio isplatu podnositelju zatražene naknade s naslova protuvrijednosti zadržanog vozila. U obrazloženju te presude, između ostaloga, navedeno je:

„Budući su se nakon podnošenja tužbe izmijenile okolnosti vezane za mogućnost vraćanja vozila u posjed tužitelja, to je tužitelj sukladno odredbi čl. 191 st. 2 ZPP-a preinačio tužbu i tužbeni zahtjev, te je predložio da sud donese presudu kojom se nalaže tuženiku da tužitelju isplati kunsku protuvrijednost iznosa od 15.000 EUR s pripadajućom kamatom od 28. 02. 2005. g. do isplate. Valja navesti da je podnesak s preinačenim tužbenim zahtjevom uredno zaprimljen od strane tuženika i da se tuženik nije usprotivio preinaci tužbenog zahtjeva ... Sud ukazuje da je tuženik tek u žalbi od 20. 02. 2006. g. prigovorio visini postavljenog tužbenog zahtjeva, ...

(...) sud je po prijedlogu tužitelja u ponovljenom postupku izveo dokaz prometnim vještačenjem po stalnom sudskom vještaku ...

Nalaz i mišljenje vještaka dostavljeni su strankama na očitovanje, time da niti tužitelj niti tuženik nisu imali prigovora na isti (...).

Sud drži da se tuženik tijekom ovog parničnog postupka nije pridržavao načela savjesnosti i poštenja propisanog čl. 12. ZOO-a, u kojem je navedeno da su sudionici u zasnivanju obveznih odnosa i ostvarivanju prava i obveza iz tih odnosa dužni pridržavati se načela savjesnosti i poštenja. Sud ovo obrazlaže činjenicom da je tuženik dopustio da tužiteljevo vozilo bude odvezeno iz njegovog autosalona ... a ... o tome nije izvijestio niti sud, niti tužitelja ... jer tijekom postupka nije dostavio nikakove dokaze na te okolnosti ... sud ukazuje da su se sudionici obveznih odnosa dužni pridržavati i načela zabrane uzrokovanja štete koje je propisano čl. 16 ZOO-a, a u kojem se navodi da je svatko dužan suzdržati se od postupka kojim se može drugom uzrokovati šteta ... Osim toga, sud drži da se tuženik tijekom postupka nije ponašao niti sukladno čl. 18 ZOO-a, a u svezi izvršavanja obveza i ostvarivanju prava. Naime, tuženik je kao sudionik u obveznom odnosu bio dužan postupati prema pravilima svoje struke i štititi interese tužitelja kao korisnika svojih usluga, jer postupanje protivno tome ima za posljedicu odgovornost za štetu koja je tužitelju uzrokovana. Stoga sud smatra da tuženik nije postupao s pažnjom koja se u pravnom prometu zahtijeva u odgovarajućoj vrsti obveznih odnosa (pažnja dobrog privrednika, odnosno pažnja dobrog domaćina), te sud također smatra da tuženik tijekom postupka nije postupao s povećanom pažnjom prema pravilima struke i običajima (pažnja dobrog stručnjaka), a u svezi s izvršavanjem obveze iz svoje profesionalne djelatnosti.

(...)

Obzirom na izmijenjene okolnosti koje su se dogodile tijekom trajanja ovog parničnog postupka, a u svezi s mogućnosti povrata stvari u vlasništvo tužitelja, koja stvar se nalazila u posjedu tuženika, sud smatra da tužitelju sukladno čl. 185 st. 3 ZOO-a pripada pravo na naknadu štete u novčanoj protuvrijednosti, jer je tužitelj 
u prvom redu postavio zahtjev za uspostavom prijašnjeg stanja, koja uspostava vraćanjem vozila nije bila moguća i nije provedena. (...)“

U ponovno izjavljenoj žalbi (21. svibnja 2009.), tuženik je, navodeći činjenice i okolnosti zbog kojih je zadržao vozilo podnositelja, iznio tvrdnju da se vozilo nalazi u njegovu posjedu, ali da odbija njegovu predaju podnositelju te se u cijelosti protivi naloženoj isplati protuvrijednosti vozila. Odlučujući o žalbi tuženika, Županijski sud u Zagrebu istu je usvojio i preinačio prvostupanjsku presudu na način da je u cijelosti odbio tužbeni zahtjev podnositelja. U obrazloženju osporene presude između ostalog je istaknuo:

„Prema shvaćanju ovoga suda, u pravu je žalitelj kada tvrdi da u konkretnom slučaju nisu ispunjene osnovne pretpostavke odgovornosti za štetu, jer u njegovu postupanju nije bilo protupravnosti, s obzirom da vozilo nije oduzeto tužitelju, već se je, u smislu odredbe čl. 286. st. 1. ZOO poslužio pravom retencije, odnosno zadržaja njegova vozila do podmirenja dospjelog potraživanja koje tužitelj ima prema njemu.

\section{(...)}

Odredbom čl. 286. ZOO propisano je da vjerovnik dospjelog potraživanja u čijim rukama se nalazi neka dužnikova stvar ima pravo zadržati je, dok mu ne bude isplaćeno potraživanje.

Prema citiranoj zakonskoj odredbi za pravo zadržaja moraju biti ispunjene dvije pretpostavke i to: da je stvar koja je predmet retencije vlasništvo dužnika i da vjerovnik kod kojega se nalazi dužnikova stvar ima dospjelo, a nepodmireno potraživanje prema njemu.

Stoga, kraj činjenice da u konkretnom slučaju postoji dospjelo potraživanje tuženika prema tužitelju s osnova nepodmirenih troškova popravka tužiteljeva vozila, ... tuženik je ovlašten isticati s uspjehom prigovor prava pridržaja tužiteljeva vozila dok mu dospjelo potraživanje od strane tužitelja ne bude podmireno.

Zbog iznijetog, pogrešno je pravno shvaćanje suda prvog stupnja da je tuženik u obvezi naknaditi štetu tužitelju u visini tržne vrijednosti tužiteljeva vozila ..., pa je na taj način sud prvog stupnja pogrešno primijenio materijalno pravo iz odredbi čl. 154. st. 1., čl. 155. i 185. ZOO, na koje se pozvao.

Iz navedenih razloga, valjalo je temeljem odredbe čl. 373. toč. 3. ZPP preinačiti prvostupanjsku presudu i odbiti tužitelja sa tužbenim zahtjevom, te presuditi kao u izreci.“ 


\section{AKTIVITET USTAVNOG SUDA REPUBLIKE HRVATSKE I PRAKSA SUDA EUROPSKE UNIJE}

Načelo savjesnosti i poštenja u jednom je slučaju bilo i predmetom ocjene ustavnosti Zakona o obveznim odnosima ${ }^{19}$ pred Ustavnim sudom RH. Grupa odvjetnika podnijela je prijedlog za pokretanje postupka za ocjenu suglasnosti s Ustavom članka 21. ZOO-a/05. Sporni članak je glasio: Kad obveza ima za činidbu iznos novca, dužnik je dužan isplatiti onaj broj novčanih jedinica na koji obveza glasi, osim kad zakon određuje što drugo. Predlagatelji ocjene smatrali su da osporena odredba nije suglasna s odredbama članaka 3. i 14. stavka 2. Ustava, navodeći da pri unošenju navedene odredbe u ZOO zakonodavac nije vodio računa o posebnim gospodarskim i monetarnim prilikama niti o povijesnim okolnostima na tlu Republike Hrvatske u posljednjih dvadesetak godina i to stoga što je u tada proteklih 17 godina došlo u dva navrata do zamjene postojeće valute novom valutom i u dva navrata do denominacije, što je dovelo do toga da dug koji je, primjerice, krajem 1988. godine iznosio 10.000.000 dinara od 1. lipnja 1994. danas iznosi 1,00 kunu. Predlagatelji su smatrali da inzistiranje zakonodavca na načelu monetarnog nominalizma u takvim okolnostima dovodi do uspostave nejednakosti građana pred zakonom, jer dugovi koji su nastali u ranijim razdobljima nemaju više nikakvu vrijednost te se vjerovnici nalaze u bitno drugačijim situacijama, što su potkrijepili brojnim matematičkim primjerima te zaključili da, iako je za sve vrijedio isti zakon, ovisno o trenutku dospjelosti pojedine novčane tražbine ili čak ovisno samo o trenutku naplativosti takve tražbine, položaj građana pred istim zakonom bitno je različit. Navedeno stanje smatrali su suprotnim načelu savjesnosti i poštenja, napominjući da su pred hrvatskim sudovima i drugim tijelima u tijeku brojni sporovi nastali u ranijem razdoblju, te smatraju da se takvo stanje može razriješiti ukidanjem osporene odredbe ZOO-a/05.

Ustavni sud ocijenio je ovako artikulirani prijedlog neosnovanim, smatrajući da se osporavajući razlozi predlagatelja u cijelosti odnose na razdoblje prije stupanja na snagu ZOO-a/05, kada je važila odredba članka 394. Zakona o obveznim odnosima ${ }^{20}$ koja je glasila: Kad obveza ima za predmet svotu novca, dužnik je dužan isplatiti onaj broj novčanih jedinica na koji obveza glasi, izuzev kad zakon naređuje što drugo.

Također je člankom 1163. ZOO-a/05 bilo propisano da se njegove odredbe neće primjenjivati na obvezne odnose nastale prije stupanja na snagu tog Zakona, a da obje navedene odredbe, i odredba članka 21. ZOO-a/05 i odredba članka 394. ZOO-a/91, propisuju isto načelo monetarnog nominalizma. Za to se načelo zakonodavac opredijelio na temelju članka 2. stavka 4. Ustava, slijedeći dominantnu zakonodavnu praksu europskih država i tradiciju hrvatskog pravnog sustava koja je bila utemeljena na sudskoj praksi prije stupanja na snagu Zakona o obveznim

19 "Narodne novine" broj 35/05. i 41/08., dalje: ZOO/05.

20 "Narodne novine" broj 53/91., 73/91., 111/93., 3/94., 7/96., 91/96., 112/99. i 88/01., daljnje: $\mathrm{ZOO} / 91$. 
odnosima 1978. godine. Navedena je zakonska odredba ostavila ugovornim stranama da kod nastanka ugovorne obveze mogu slobodno ugovoriti različita sredstva da se zaštite od rizika promjene vrijednosti novca, ugovarajući valutnu klauzulu (članak 22. stavak 1. ZOO-a/05), indeksnu klauzulu (članak 23. ZOO-a/05) ili kliznu skalu (članak 24. ZOO-a/05). Nadalje, člankom 369. ZOO-a/05 propisano je postupanje uslijed promijenjenih okolnosti ${ }^{21}$ te je stavkom 1 . te zakonske odredbe propisano da ako bi zbog izvanrednih okolnosti nastalih nakon sklapanja ugovora, koje se nisu mogle predvidjeti u vrijeme sklapanja ugovora, ispunjenje obveze za jednu ugovornu stranu postalo pretjerano otežano ili bi joj nanijelo pretjerano velik gubitak, ona može zahtijevati izmjenu ili čak raskid ugovora. Na taj način, vjerovnik ugovora u kojemu je valuta obveze izražena u kunama u vrijeme izvanrednih poremećaja na tržištu koje nije mogao predvidjeti u trenutku sklapanja ugovora (u kakve se promjene može podvesti, pod određenim uvjetima, i hiperinflacija o kojoj govore predlagatelji u svom prijedlogu), može od suda zatražiti izmjenu ili raskid ugovora, pod zakonom podrobno određenim uvjetima.

Uzevši u obzir sva navedena sredstva za zaštitu vjerovnika koja su određena navedenim odredbama ZOO-a/05, Ustavni je sud utvrdio da osporenim člankom 21. ZOO-a/05 nije dovedena u pitanje jednakost svih pred zakonom koja je propisana člankom 14. stavkom 2. Ustava, jer se navedena odredba primjenjuje jednako na sve sudionike obveznih odnosa, a kod nastanka ugovornih odnosa stranke su potpuno slobodne svoje tražbine zaštititi jednim od sredstava koja su pobliže uređena zakonskim odredbama.

Uz apstraktnu kontrolu pojedinih zakona kroz načelo savjesnosti i poštenja, Ustavni je sud proveo i konkretnu kontrolu sudske odluke u glasovitoj odluci "Švicarski franak" 22 koja je kao lajtmotiv uzela upravo pravičnost i poštenost kreditnih plasmana vezanih uz valutnu klauzulu švicarskog franka čija je vrijednost rapidno rasla i time povećavala rate kreditnih partija do razine nepravičnosti. $\mathrm{U}$ tom slučaju, postupku pred Ustavnim sudom prethodio je parnični postupak koji je bio pokrenut na temelju članka 132. stavka 2. Zakona o zaštiti potrošača ${ }^{23}$ i članaka 1. i 2. Uredbe o određivanju osoba ovlaštenih za pokretanje postupka radi zaštite kolektivnih interesa potrošača. ${ }^{24}$

Parnični postupak pokrenut je tužbom Potrošača protiv osam banaka. U tužbi je Potrošač naveo da je do povrede kolektivnih interesa i prava potrošača (korisnika kredita) došlo zbog sklapanja ugovora o kreditima koji sadrže nepoštene ugovorne odredbe koje se odnose na ugovorenu valutu obveze švicarski franak uz koju je vezana glavnica i one kojima je bankama omogućeno mijenjati visinu kamatne stope.

21 Clausula rebus sic stantibus.

22 Broj: U-III-2521/2015, U-III-2536/2015, U-III-2547/2015, U-III-2565/2015, U-III-2603/2015, U-III-2604/2015, U-III-2605/2015 od 13. prosinca 2016.

23 "Narodne novine" broj 79/07. i 79/09.

24 "Narodne novine" broj 124/09.; dalje: Uredba. 
Prvostupanjski sud utvrdio je da su banke i Sberbanka povrijedili kolektivne interese i prava potrošača na način da su, u određenom razdoblju - što je dovelo do neravnoteže u pravima i obvezama ugovornih strana - ugovarali valutu "uz koju je vezana glavnica švicarski franak", a da potrošače nisu u cijelosti informirali o svim potrebnim parametrima bitnima za donošenje valjane odluke te da su ugovarali kamatnu stopu koja je tijekom postojanja obveze po ugovorima o kreditima bila promjenjiva u skladu s jednostranom odlukom banaka i drugim internim aktima banaka, a da banke i potrošači nisu prije i u vrijeme zaključenja ugovora o kreditu o takvoj ugovornoj odredbi pojedinačno pregovarali niti su ugovorom o kreditu utvrdili egzaktne parametre i metodu izračuna tih parametara koji utječu na odluku banaka o promjeni stope ugovorene kamate.

Prvostupanjski sud naložio je bankama i Sberbanci da prekinu s gore opisanim postupanjem te im naložio da u roku od šezdeset dana ponude potrošačima izmjenu ugovorne odredbe na način da glavnica kreditne obveze bude izražena u kunama u iznosu koji je isplaćen u fazi korištenja kredita i uz fiksnu kamatnu stopu u postotku koji je bio izrijekom naveden u sklopljenom potrošačkom ugovoru kao važeća stopa redovne kamate na dan sklapanja ugovora. Zabranio je bankama i Sberbanci takvo i slično postupanje ubuduće te im naložio da Potrošaču solidarno isplate troškove parničnog postupka.

Prvostupanjski sud odbacio je tužbeni zahtjev u dijelu kojim je Potrošač zatražio od suda da bankama i Sberbanci naloži da potrošačima ponude izmjenu ugovorne odredbe na način da glavnica bude vezana uz euro te da kamatna stopa bude ugovorena na način kako je to pobliže označeno točkom 2. izreke prvostupanjskog rješenja.

Drugostupanjskom odlukom (presudom i rješenjem) djelomično je potvrđena, djelomično preinačena te djelomično ukinuta prvostupanjska odluka.

Drugostupanjskom odlukom prvostupanjska odluka je preinačena u odnosu na ugovornu odredbu o valuti obveze. Drugostupanjski sud utvrdio je da ta odredba ispunjava zahtjeve razumljivosti pa s time nije nepoštena, a posljedično nije ni ništetna.

Drugostupanjski sud potvrdio je prvostupanjsku odluku u dijelu koji se odnosi na ništetnost ugovorne odredbe o promjenjivoj kamatnoj stopi (osim u pogledu Sberbanke, u kojem je dijelu prvostupanjsku odluku preinačio na način da je taj dio tužbenog zahtjeva odbio). Potvrdio je stajalište prvostupanjskog suda da je riječ o nepoštenoj ugovornoj odredbi koja je potrošačima nametnuta jednostranom odlukom banaka, o kojoj se nije pojedinačno pregovaralo.

Osporenom odlukom Vrhovni sud je revizije Potrošača i banaka odbio kao neosnovane. ${ }^{25}$

25 Prigovori Potrošača u bitnome sveli su se na tvrdnje o povredi prava na pravično suđenje zajamčenog člankom 29. stavkom 1. Ustava i člankom 6. Konvencije. Za ocjenu osnovanosti prigovora podnositelja, između ostaloga, mjerodavni su i članak 84. te članci 96. stavci 1. i 2., 99. Zakona o zaštiti potrošača, koji propisuju nedopuštenost ocjene pojedinih ugovornih odredaba i nepoštene odredbe u potrošačkim ugovorima. 
Ustavni sud konzultirao je i mjerodavnu praksu Suda Europske unije u predmetu broj: C-26/13 (presuda od 30. travnja 2014., Kásler i Káslerne Rábai, ECLI:EU:C:2014:282, donesena u povodu zahtjeva Kurie - mađarskog suda za prethodno pitanje o tumačenju članka 4. stavka 2. Direktive 93/13/EEZ, tzv. "mađarski slučaj") u kojem je Sud EU-a zauzeo sljedeće stajalište:

,(...) članak 4. stavak 2. Direktive 93/1326 treba tumačiti na način da, kada je riječ o ugovornoj odredbi kao što je ona u glavnom postupku, zahtjev prema kojem ugovorna odredba mora biti jasno i razumljivo sastavljena podrazumijeva obvezu ne samo da konkretna odredba potrošaču bude gramatički razumljiva nego i da ugovor razvidno izloži funkcioniranje konkretnog mehanizma konverzije u stranu valutu na koji se poziva dotična odredba kao i odnos između tog mehanizma i mehanizma propisanog drugim odredbama koje se tiču isplate kredita, tako da potrošač na temelju točnih i razumljivih kriterija bude u stanju procijeniti ekonomske posljedice koje iz toga za njega proizlaze."

U odnosu na članak 5. Direktive 93/13/EEZ, Sud EU-a je naveo:

,$\ldots$. navedena obveza u pogledu jasnoće i razumljivosti teksta primjenjuje se u svakom slučaju, čak i kad je odredba obuhvaćena člankom 4. stavkom 2. Direktive 93/13 te je izuzeta od ocjene nepoštenosti iz članka 3. stavka 1. iste direktive.

\section{(...)}

Obveza transparentnosti ugovornih odredbi koju postavlja Direktiva 93/13 ne može se ograničiti isključivo na značajku razumljivosti na formalnoj i gramatičkoj razini.“

Ustavni je sud u ocjeni nadalje istaknuo da Potrošač u ustavnoj tužbi izrijekom navodi kako ne osporava zakonsku odredbu na temelju koje je dopušteno ugovaranje valutne klauzule, kao ni činjenicu da ona postoji i proizvodi pravne učinke u pravnom sustavu Republike Hrvatske. Međutim, smatra da su banke zloupotrijebile navedenu zakonsku odredbu kada su potrošače poticale na sklapanje ugovora $s$ valutnom klauzulom vezanom uz švicarski franak. Istaknuo je da se banke nisu zaduživale u švicarskim francima, već su konkretne kredite plasirale iz štednje građana. Smatra, također, da sklapanju ugovora o kreditima s takvom valutnom klauzulom nije bilo mjesta u situaciji kada je vrijednost kune stabilna. Međutim, navedene prigovore Potrošača nije razmatrao u ovom ustavnosudskom postupku, jer će se ti prigovori razmatrati u postupcima apstraktne kontrole u kojima se osporavaju pojedine odredbe Zakona o izmjeni i dopunama Zakona o potrošačkom kreditiranju $^{27}$ i Zakona o izmjeni i dopunama Zakona o kreditnim institucijama. ${ }^{28}$

26 Članak 4. stavak 2. Direktive 93/13/EEZ glasi:

„Članak 4.

(...)

(2) Procjena o tome jesu li neke odredbe nepoštene ne odnosi se na definiciju glavnog predmeta ugovora ni na primjerenost cijene i naknade na jednoj strani, $i$ isporučene usluge i robu, na drugoj, sve dok su te odredbe jasno i razumljivo sastavljene."

27 "Narodne novine" broj 102/15. - predmet broj: U-I-3685/15 i dr.

28 "Narodne novine" broj 102/15. - predmet broj: U-I-3737/15 i dr. 
Ustavni sud utvrdio je da citirana stajališta Suda Europske unije u tumačenju i primjeni Direktive 93/13/EEZ - na koju su se pozvali nižestupanjski sudovi i Vrhovni sud - jasno naglašavaju važnost (informiranog, upućenog) obavještavanja potrošača prije sklapanja ugovora o ugovornim uvjetima i njihovim posljedicama. Takvo obavještavanje od bitne je važnosti za potrošača jer će samo na temelju prethodne, potpune i razumljive obavijesti potrošač biti u situaciji razumno shvatiti i predvidjeti posljedice i ekonomske učinke koje za njega može imati sklapanje ugovora s takvim ugovornim odredbama.

Praksa Suda Europske unije navedena u osporenim odlukama sudova (broj: C-26/13 od 30. travnja 2014.) odraz je ustaljenog stajališta da se potrošač nalazi u slabijem položaju u odnosu na poduzetnike (u konkretnom slučaju banke), kako u pogledu pregovaračke snage, tako i u pogledu razine obaviještenosti, odnosno položaja koji vodi do pristanka na uvjete što ih je poslovni subjekt prethodno sastavio, bez mogućnosti utjecaja na njihov sadržaj. Upravo zbog tog slabijeg položaja potrošača, Direktiva 93/13/EEZ obvezuje države članice da propišu mehanizam koji će osigurati da bilo koja ugovorna odredba o kojoj se nije pojedinačno pregovaralo može biti podvrgnuta ispitivanju kako bi se ocijenilo je li eventualno nepoštena.

Nadalje je utvrđeno da je Vrhovni sud ocijenio kako presuda Suda Unije broj: C-26/13 nije relevantna za ocjenu poštenosti ugovaranja valutne klauzule (za razliku od njezine relevantnosti za ocjenu poštenosti ugovorne odredbe o promjenjivoj kamatnoj stopi), s obzirom na to da ,činjenični supstrat opisanog mađarskog i ovog predmeta nije istovjetan, te se međusobno i ne mogu uspoređivati niti dovoditi u vezu“. Međutim, Vrhovni sud nije naveo dostatne i relevantne razloge za zaključak o postojanju takve bitne različitosti činjeničnih supstrata koja bi onemogućila da se i u konkretnom slučaju primijeni načelno pravno stajalište Suda EU (iz mađarskog slučaja) o pitanju tumačenja pojma razumljivosti ugovorne odredbe, iako se u oba slučaja upravo radi o ugovornoj odredbi o valutnoj klauzuli vezanoj uz švicarski franak. Budući da obrazloženje osporene odluke Vrhovnog suda o tome ništa ne sadrži, Ustavni sud ne može utvrditi razloge na temelju kojih je Vrhovni sud izveo navedeni zaključak.

Također je utvrđeno da je Vrhovni sud propustio očitovati se na prigovore Potrošača i banaka u kojima oni traže da se Sudu Europske unije uputi zahtjev za donošenje odluke o prethodnom pitanju o tumačenju članka 4. stavka 2. Direktive 93/13/EEZ. U vezi s navedenim, Ustavni sud ističe da Vrhovni sud nije dužan prihvatiti sve prijedloge stranaka, uključujući i one koji se odnose na podnošenje zahtjeva Sudu EU za prethodno tumačenje prava EU-a. Odluka o tome hoće li takav zahtjev uputiti ili ne, u nadležnosti je Vrhovnog suda i ne ovisi o dispoziciji stranaka. Međutim, u svakom slučaju, kao „nacionalni sud zadnje instance“ bio je dužan očitovati se odnosno obrazložiti razloge zbog kojih smatra da u konkretnom slučaju nije bio dužan pokrenuti prethodni postupak odnosno uputiti zahtjev Sudu Europske unije za prethodno tumačenje prava EU-a u smislu članka 267. stavka 3. Ugovora o funkcioniranju EU-a. 
Imajući u vidu citirani sadržaj sporne ugovorne odredbe Sberbanke o promjenjivoj kamatnoj stopi, proizlazi da je potrošačima iz ugovora o kreditu zaključenima sa Sberbankom bilo poznato da će se korekcija visine ugovorene promjenjive kamatne stope provesti u odnosu na LIBOR, kao jedan od zakonom propisanih parametara. Međutim, Ustavni sud primjećuje da članci Zakona o potrošačkom kreditiranju na koje se poziva Vrhovni sud, isto tako propisuju obvezu vjerovnika (banaka) da potrošačima prije sklapanja ugovora o kreditu ,jasno i nedvojbeno predoče“ sve elemente promjenjive kamatne stope, pa tako i troškove pribavljanja sredstava i kreditnu maržu kreditora (Sberbanke).

Iz obrazloženja osporene odluke ne proizlazi da je Vrhovni (i drugostupanjski) sud prilikom ocjene nerazumljivosti ove ugovorne odredbe imao u vidu ponašanje Sberbanke, to jest činjenicu je li Sberbanka postupila na propisani način i je li potrošačima na ,jasan i nedvojben“ način prije zaključenja ugovora o kreditu predočila sve elemente promjenjive kamatne stope te ih upozorila na sve rizike takve promjenjivosti. Točno je da sporna ugovorna odredba Sberbanke sadrži to da promjena kamatne stope ovisi o „troškovima pribavljanja sredstava“ i ,kamatne marže Kreditora“". Međutim, iz obrazloženja osporene odluke ne proizlazi na temelju kojih su podataka potrošači mogli znati koliko takvi troškovi i marža iznose, na koji način se mijenjanju, te o čemu ovisi promjena visine tih elemenata.

Ustavni je sud prilikom ocjene razumljivosti ugovornih odredaba o valutnoj klauzuli utvrdio da obrazloženje Vrhovnog suda i u odnosu na pitanje nepoštenosti ugovorne odredbe o promjenjivoj kamatnoj stopi Sberbanke ne udovoljava mjerilima dostatnosti i relevantnosti koje postavlja zahtjev pravičnog suđenja. Iz obrazloženja osporene odluke, naime, nisu razvidni dostatni i relevantni razlozi na temelju kojih je Vrhovni sud ocijenio da bi ovako formulirana sporna ugovorna odredba, iako sadržajno različita od ugovorne odredbe o promjenjivoj kamatnoj stopi ostalih tuženika (banaka), bila potrošačima razumljiva, posebice u odnosu na ekonomske posljedice koje iz takve ugovorne odredbe proizlaze za potrošače, neovisno o tome što eventualno i sadrži parametre koje je propisao mjerodavni zakon.

Slijedom navedenoga, ocjena je Ustavnog suda da je Vrhovni sud propustio iznijeti dostatne i relevantne razloge zbog kojih smatra da je osporena ugovorna odredba, na način kako ju je ugovorila Sberbanka, bila razumljiva i izuzeta iz testa nepoštenosti.

Kako pojam savjesnosti i poštenja ne bi bio samo teorijsko načelo, uz redovne sudove, Ustavni sud i druga državna tijela, poželjne su organizacije ili tijela koja 
će se u svojem radu posvećivati upravo etici kao temelju poslovanja, kao što je to primjerice Centar za poslovnu etiku u Zagrebu. ${ }^{29}$

\section{UMJESTO ZAKLJUČKA}

Vrhovni sud Republike Hrvatske u presudi broj: Rev 1333/07-2 od 4. veljače 2009. naveo je, između ostaloga, kako su nižestupanjski sudovi, polazeći od utvrđenog činjeničnog stanja, ispravno primijenili materijalno pravo obvezavši podnositelja na iseljenje i predaju predmetnog poslovnog prostora tužitelju ,temeljem odredbi Zakona o obveznim odnosima ("Narodne novine", broj: 53/91, 73/91, 3/94, 7/96 i 112/99 - dalje: ZOO). Ovlaštenje tužitelja kao zakupodavca tražiti iseljenje i predaju spornog prostora proizlazi iz općih načela obveznih odnosa od kojih jedno od njih jest načelo savjesnosti i poštenja iz čl. 12. ZOO-a, a prema kojem su se sudionici obveznih odnosa dužni pridržavati načela savjesnosti i poštenja. To u konkretnom slučaju znači da je tužitelj u cilju savjesnog gospodarenja predmetnim poslovnim prostorom bio dužan tražiti njegovu predaju odnosno obvezu tuženika predati taj prostor tužitelju a nakon što je ugovor o zakupu raskinut. Takvo ovlaštenje tužitelja konačno proizlazi posredno iz odredbe čl. 132. ZOO-a.“

Ovaj citat klasičan je primjer na koji način u konkretnim sudskim predmetima redovni sudovi razmatraju postupanje stranaka u kontekstu načela savjesnosti i poštenja, načela koje predstavlja neizostavan element u odlučivanju, uz mjerodavno materijalno pravo primjenjivo u razmatranom slučaju. Načelo savjesnosti i poštenja u konačnici je imanentno pojmu pravičnog (poštenog) suđenja, za što je načelna stajališta ustanovio i implementirao ih u svoje odluke Ustavni sud. Ono se odnosi na članak 29. stavak 1. Ustava koji u mjerodavnom dijelu glasi: „Svatko ima pravo

29 Centar za poslovnu etiku (CEP) nalazi se u prostorijama Fakulteta filozofije i religijskih znanosti Sveučilišta u Zagrebu. S radom je započeo potkraj 2004. godine i od tada gradi ugled jake znanstvene organizacije koja se zauzima za unapređenje poslovne etike kao znanstvene discipline i primjenu etičkih načela u svakodnevnom poslovnom i osobnom životu. Članovi Centra su profesori, doktori i magistri filozofskih i ekonomskih znanosti, studenti dodiplomskog i poslijediplomskog studija u Hrvatskoj i inozemstvu, te sve osobe zainteresirane za zajednički rad u Centru.

Centar za poslovnu etiku osnovan je s ciljem promicanja primjene etičkih načela, pomoći pri rješavanju etičkih dvojbi, stručnog i znanstvenog usavršavanja članova, te znanstvenog doprinosa na području etike kao znanstvene discipline. U svom djelovanju Centar za poslovnu etiku zalaže se za najvišu razinu profesionalnog djelovanja, a sve to poradi primjene i prihvaćanja etičkih načela u životu i radu. Centar želi pomoći u rješavanju moralnih dvojbi svake pojedine osobe koja zatraži njegovu pomoć. Centar nastoji biti mjesto na koje se svatko može obratiti s povjerenjem, mjesto gdje može potražiti savjet $u$ dilemi kako riješiti etičke dvojbe, kako odrediti i primijeniti etička načela u konkretnom životu te pomoći pravnim i fizičkim osobama u stvaranju internih načela profesionalne etike kako bi zaposlenici imali jasna pravila poslovnoga ponašanja, a sve radi smanjenja nezakonitih radnji i stvaranja boljega radnog okruženja. U tom smislu Centar organizira simpozije i konferencije na kojima želi okupiti ljude koji će o nekom problemu razmišljati iz perspektive osobnog, profesionalnog, filozofskog, iz perspektive raznih religija i kršćanskog morala, etike i duhovnosti. "Treba nam etika vrijednosti u kojoj je na prvom mjestu čovjekovo, ljudsko dostojanstvo. Istinski etički izazov nije nužno na "pravilnom” (regulativnom) razrješenju sivih zona gospodarske svakodnevice, i međuljudskih odnosa nego u oživljavanju i bdjenju na trajnoj svijesti o vrijednosti i dostojanstvu ljudske osobe.” prof. dr. sc. Ivan Koprek, izvor: http://www. cep.ffdi.hr/index.php/o-nama, stranica posjećena 10. lipnja 2018. 


\title{
da zakonom ustanovljeni neovisni i nepristrani sud pravično ... odluči o njegovim pravima i obvezama (...)“.
}

\begin{abstract}
Since antiquity obligations in Roman law were protected by lawsuits, (actiones bonae fidei), if they were based on the principles of good faith (bona fides - and fairness - aequitas). Both then and today, in adjudicating such lawsuits, the judge must examine all the facts and circumstances that have accompanied the conclusion of the legal transaction in order to make a valid and lawful legal conclusion. The following article presents some current case law examples, which show the conduct of ordinary courts in deciding on compulsory relations in the context of the principle of conscientiousness and honesty, and shows selected decisions of the Constitutional Court of the Republic of Croatia that covered the issue of conscientiousness and honesty in obligatory relations through the prism of fundamental, constitutionally guaranteed, human rights and the assessment of possible violation thereof.
\end{abstract}

Keywords: conscientiousness, honesty, bona fides 